\title{
Trvalá udržitelnost Deblínska: Vzdělávací projekt
}

\author{
Alois Hynek, Břetislav Svozil, Jan Trávníček, Jakub Trojan \\ Envigogika 2009/IV/2 - Recenzované články/ Reviewed Papers \\ Publikováno/Published 30. 09. 2009
}

DOI: http://dx.doi.org/10.14712/18023061.40

\begin{abstract}
Abstrakt:
Vzdělávací projekt Geografického ústavu PřF MU v Brně zaměřený na trvalou udržitelnost krajiny Deblínska na Tišnovsku spojil univerzitu, základní školu, veřejnou správu a dospělou veřejnost $v$ praktické poloze posílení environmentálního vědomí i praktických kroků ve zlepšení kvality životního prostředí - významné krajinné prvky, oběh vody. Prokázal tak možnosti zlepšení trvalé udržitelnosti krajiny i v prípadě, kdy chybí Místní agenda 21.
\end{abstract}

Tento článek byl prezentován na konferenci "Metody a možnosti ve výuce udržitelnosti na VŠ"

\section{Klíčová slova:}

Trvalá udržitlenost, projektová výuka, kulturní krajina, Jižní Morava, Deblín

\begin{abstract}
:
The topic of this contribution was an educational project in study programme of Department of Geography, Faculty of Science, Masaryk University in Brno, the school year 2008/09. Teaching/learning the sustainability was based on joint deduction, induction and abduction in study groups emphasizing fieldwork in Deblín-town area, in the west of Brnocity. Supported by cooperation of university, basic school and Deblín-town community, among others in two public evening sessions. Public administrative body from the town of Tišnov, Department of environment and the management of Deblín-microregion also assisted in the project. With respect to Millenium Ecosystem Assessment the main stakeholders/actors were included for their important role in cultural landscape ecosystems sustainability. Strong social accent on children, youth, experts, public administration and adult public participation carried out community requirements. Studying environmental perception and participation, GIS technology application in the frame of multiple method in geographical research based on field survey and remote sensing data offered new knowledge. It was used, e.g. for revision of landscape protection, improving hydro-cycle for public benefit.
\end{abstract}

\section{Key words:}

Sustainability, project training, cultural landscape, South Moravia, Deblín 


\section{Úvod}

Téma příspěvku bylo vzdělávacím projektem ve studijním programu Geografického ústavu PřF MU v Brně ve školním roce 2008/09. Výuka/učení trvalé udržitelnosti byla založena na propojení dedukce, indukce a abdukce ve skupinové výuce s posílením výuky terénní na Deblínsku (část Tišnovska). Opírala se o spolupráci MU, ZŠ v Deblíně a obyvatel Deblínska mj. uskutečněné i dvěma večerními setkáními $s$ veřejností. Projekt byl podporován odborem životního prostředí MěÚ $v$ Tišnově a mikroregionem Deblínsko. $\checkmark$ souladu $s$ Millenium Ecosystem Assessment bylo hlavním cílem projektu propojení aktérů, jejichž role $v$ udržitelnosti kulturní krajiny jako souboru ekosystémů je nezastupitelná. Silný sociální akcent na zastoupení dětí, mládeže, odborníků, veřejné správy a dospělé veřejnosti naplňuje i požadavky komunitního př́stupu. Studium percepce a participace životního prostředí obyvateli Deblínska bylo zahrnuto do geografického studia území za použití terénních metod, technologie GIS souborem více metod (triangulace, multiple method). Zájem žáků, studentů, veřejné správy i dospělé veřejnosti byl nad míru našeho očekávání a vedl mj. k praktické revizi stavu významných krajinných prvků v katastru Deblína, a k návrhu lepšího využití oběhu vody.

Na Geografickém ústavu (GÚ) Masarykovy univerzity v Brně se autorský kolektiv pod vedením $A$. Hynka dlouhodobě věnuje realizaci projektové výuky zaměřené na studium urbánně-rurálních vztahů, s dưrazem na udržitelnost a bezpečnost území/krajiny/regionu. Tyto otázky jsou řešeny v rámci předmětů Z0131 Sustainability - Trvalá udržitelnost (zimní semestr) a Z0132 Urbánní a rurální studia (letní semestr). Testování možností projektového pojetí probíhalo především na území Jihomoravského kraje $v$ rámci fyzickogeografického a sociálního průzkumu Pouzdřan (Hynek, Svozil 2007) a hledání trvalé udržitelnosti a bezpečnosti Klentnice (Svozil, Trávníček 2007) se závěrečným workshopem $s$ veřejností $v$ zájmové obci. Autorský tým při práci se studenty překročil hranice Jihomoravského kraje do sousedních krajů (Svozil et al. 2008) i států (Hynek et al. 2008) v mezinárodním řešitelském kolektivu (Hynek et al. 2007). Od září 2008 probíhá projektová spolupráce základní školy (ZŠ) Deblín a GÚ $s$ Úřadem městyse Deblín a Městským úřadem Tišnov v projektu Trvalá udržitelnost Deblínska.

\section{Projekt Trvalá udržitelnost Deblínska}

Současný projekt rozšiřuje model projektové výuky o spolupráci s žáky místní ZŠ jakožto nositeli interních znalostí a vazeb v zájmovém území. Právě zapojení Zš v pozici rovnocenného partnera $\mathrm{k}$ univerzitnímu pracovišti představuje podstatnou inovaci projektové kooperace. Žáci pomáhají studentům geografie proniknout do konstrukce a fungování místní komunity a sami spoluprací získávají nadhled a odbornost. Společné řešení udržitelnosti usiluje o aktivaci a participaci subjektů, které žijí anebo nějakým způsobem ovlivňují Deblínsko. Aktivita žáků pomáhá vzbudit zájem místních obyvatel o okolí jejich bydliště, rozvíjí jejich citlivost k principům udržitelného rozvoje, př́ípadně je stimuluje k aktivnímu zapojení do projektu. 


\section{Obr.1: Lokalizace Deblínska v rámci Jihomoravského kraje}

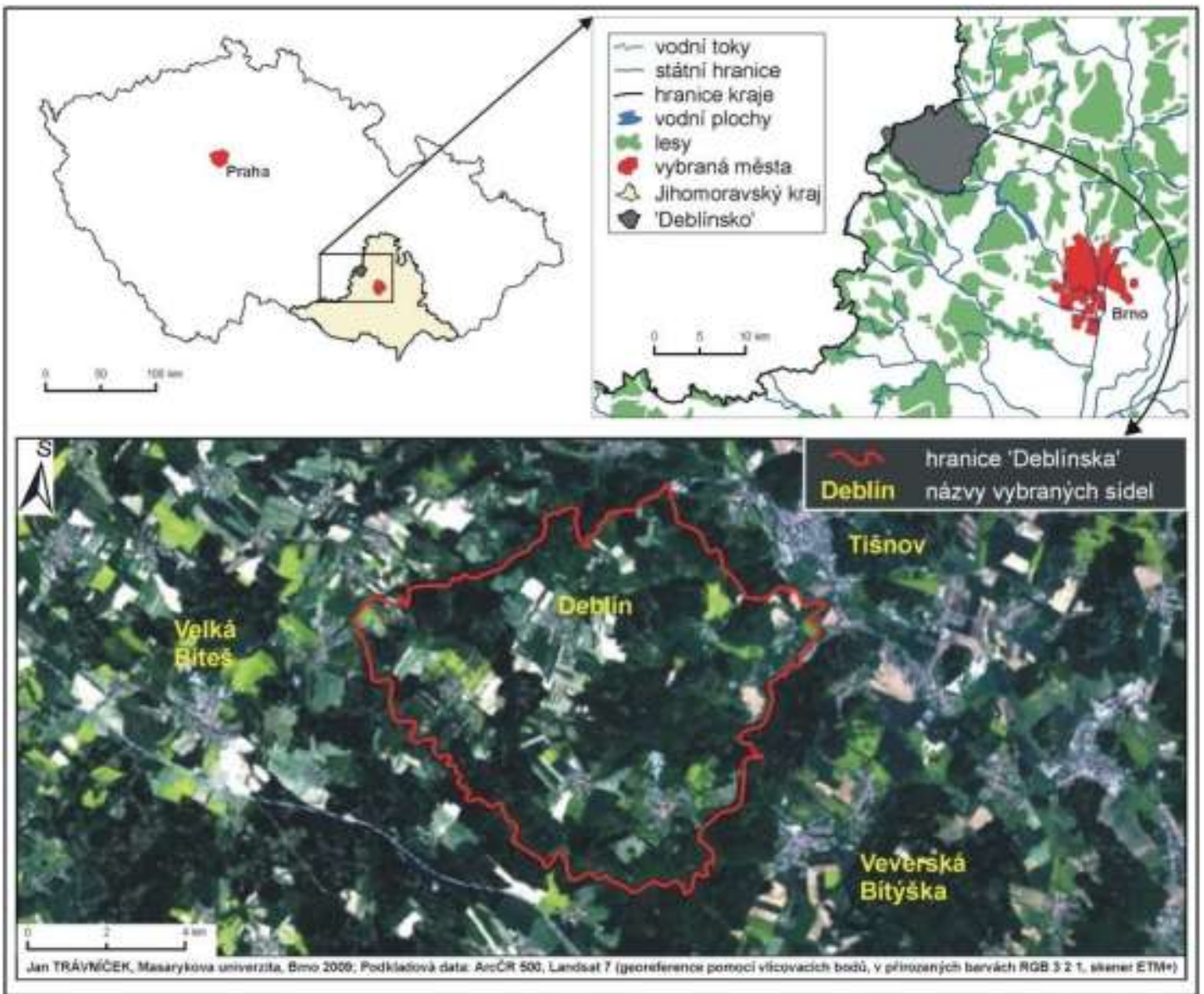

Projekt se váže na území 'Deblínska' vymezené s ohledem na 'Dobrovolný svazek obcí Deblín', integrované dopravní spojení, historické i současné vazby na centrální Deblín a přírodní podmínky (obr. 1). Pro žáky i studenty představuje projekt výjimečnou možnost podílet se na výstupech, které jsou postupně předkládány a diskutovány se zástupci veřejné správy i místní samosprávy s cílem zohlednit či uplatnit je v praxi.

\section{Metody}

Vzdělávací cíl projektu je zaměřen na studium Deblínska, na detailní poznání lokálního prostředí, které předpokládá pochopení komunitních problémů z pohledu místních lidí a významných aktérů, kteří mají na chod a udržitelnost komunity/území vliv. Dưraz je kladen na identifikaci hlavních problémů rozvoje, environmentální bezpečnosti území a na návrhy řešení, které vycházejí zevnitř, ale jsou relačně propojeny zvenčí území. Environmentální podoba výzkumu vychází z rozlišení přírodních a kulturních krajinných ekosystémů, interpretovaných podle pojetí 'The Millennium Ecosystem Assessment' (Alcamo et al. 2003). Komunitní výzkum byl zacílen na environmentální vnímání, představy (i prostřednictvím mentálních map) a jednání místních obyvatel, studentů a návštěvníků. Politicko-sociální poloha výzkumu byla zaměřena na environmentální praxi, relaci veřejné správy (státní správa a samospráva), komunit obcí a soukromého sektoru a její konkrétní projevy v krajině. 


\section{ESPECT/TODS, kombinace kvantitativních a kvalitativních metod}

Metodologickým základem výzkumu je přístup ESPECT/TODS (Hynek, Hynek 2007), který umožňuje izolovaně studovat jednotlivé složky sociální reality z hlediska prostorovosti a emergence moci. Vstupujeme do 'neznámé' lokality, ve které se identifikují důležití aktéři - rozkrývají sítě, ze kterých vychází interaktivní propojení s okolím. ESPECT/TODS zahrnuje 6 pilířo (Economy, Society, Politics, Ecology, Culture, Technology) environmentální udržitelnosti/bezpečnosti. O jednotlivých pilírích mưžeme mluvit jako o determinantech, které působí v sociokulturním systému. Na každý pilír se musí nahlížet jako na produkt pưsobení ostatních pilírư. Interakce faktorů projevujících se ve zkoumaném území není vyvážená či neutrální. Prostorově se projevují dominující faktory, které způsobují i heterotopii v pojetí M. Foucaulta. Esenci heterotopie vystihuje vnitřní jádro šestiúhelníku zahrnující časoprostor nadvlády a podřizenosti. Nově pak je využit i Foucaultův koncept biopolitiky (2009/2004).

Při studiu lokalit využívá autorský kolektiv kvalitativní výzkumné přístupy, přičemž neopomíjí ani kvantitativní data, které svými možnostmi přispívají k prohloubení znalostí o sociálně konstruované realitě. Komplementarita obou př́stupů přirozeně vede k jejich kombinacím a získané výsledky se vzájemně doplňují. Po roce 2000 stoupá na významu tzv. smíšený výzkum (např. Tashakkori, Teddlie 1998, 2003; Fay, 2002) neboli využití kvantitativních a kvalitativních metod, technik nebo paradigmat/výzkumných programů $\checkmark$ rámci jedné studie. $\mathrm{V}$ tomto ohledu je důležité zmínit inspirativní použití abdukce v geografickém výzkumu. Podstata abdukce tkví v terénním ověření návaznosti indukce a dedukce (Holt-Jensen 2001), bez abdukce jde o formální myšlenkový akt. Dalším použitým konceptem je Actor-Network Theory (ANT), jejímž autorem je Bruno Latour (2005). ANT, který se řadí mezi poststrukturalistické přístupy, mimo jiné podněcuje nové environmentální diskurzy a jako takový se stále výrazněji uplatňuje i v humánní geografii (např. Crang, Thrift 2000). ANT se zabývá mj. prolínáním společnosti a přírody, jejich hybriditou i separací, živými aktéry a neživými aktanty (Whatmore 2002, Murdoch 2006). Výzkumná metodologie tedy nevychází pouze ze spolupráce s geografickými vědami, ale čerpá $z$ interdisciplinární spolupráce $s$ negeografickými vědami jako je etnografie, antropologie, sociologie, filosofie a psychologie, může být realizována jako transdisciplinární.

\section{Techniky sběru a posouzení informací}

Výukový proces je založen na vytváření výzkumných situací a jejich společném řešení žáky, studenty i učiteli - nikdo nezná předem výsledek, učitelé mají náskok jen svými zkušenostmi, ale žáci a studenti mají výhodu větší volnosti v hledání řešení. Žáci i studenti $v$ rámci projektového vyučování kombinují primární a sekundární zdroje informací, doplněné terénním výzkumem a posuzováním validity získaných informací svyužitím metodologické triangulace.

Jádrem primárních technik je: zúčastněné pozorování směřující k identifikaci časoprostoru (kde a jak se věci dějí), nestrukturované nebo semistrukturované rozhovory čerpající mimo jiné ze souboru 80 otázek formulovaných pro studium území/místa localitylocales-locuses Hynkem (2005), aplikovaných pomocí kvótního výběru dle statistických dat (věk, vzdělání, pohlaví, trvalé bydliště) a veřejné diskuse (během veřejných přednášek). Mezi sekundární techniky patřila obsahová analýza dostupných pramenů (zprávy, dokumenty, muzejní materiály, kroniky, bibliografické a autobiografické materiály, literatura, časopisy, periodika, internet, fotografie, narativní vyprávění a mentální mapy). Narativní prístup pomohl získat různé perspektivy a interpretace respondentů. Bylo důležité akceptovat historickou lokální pravdu konstruovanou v myslích místních obyvatel, která silně ovlivňuje i současné významové struktury.

Základem pro studium jednotlivých lokalit byl kvalitativní terénní výzkum orientovaný etnograficky ve smyslu 'thick description' neboli zhuštěného popisu. Tento pojem uvedl do povědomí Clifford Geertz, který upřednostňoval weberovský přístup vycházející z porozumění sociokulturním jevům. Filosof Fay (2002) mluví dokonce 
o existenci různých stupňů zhuštěnosti. Postupná proměna z role pozorovatele (cizince) až po člena komunity umožnila pronikat do lokálních specifik a porozumět perspektivám jednotlivých aktérů. Koncept bezezbytku naplnil člen autorského kolektivu více než rok žijící ve studovaném území. V roli učitele získal sociální status zahrnující implicitní očekávání členů komunity, uznávání předpisů, norem, hodnot, zvyků, pravidel a vzorů chování. Není zatížen lokálními stereotypy, což umožňuje odkrývat jednotlivé hlubinné vrstvy reality, které jsou běžnému návštěvníkovi nepřístupné/neviditelné a nebo jsou viditelné jen zčásti. Zjednodušeně bychom mohli zhuštěný popis označit jako strategii sběru dat, která umožňuje na základě analýzy a popisu konkrétních lokálních událostí dosáhnout analýzy $v$ širších politických a kulturních souvislostech. V současné humánní geografii tento termín zmiňuje např. Cloke (et al. 2004, s. 308).

Validita kvalitativního výzkumu byla ověřována za využití tzv. triangulace. Triangulace (též označovaná jako multiple-method) vybízí k pravidelnému revidování průběžných výsledků a $\mathrm{k}$ případným změnám. Při projektové spolupráci byla triangulace využita jako metoda vedoucí jak k obohacování, tak k doplňování výsledků výzkumu. Byly aplikovány čtyři typy triangulace: datová, teoretická, metodologická a triangulace výzkumníků.

\section{Koncepce projektového vyučování, cíle projektu}

$V$ edukační sféře poskytuje navržený model projektové výuky (metodický základ a metody výzkumu) aplikační platformu pro ověřování a využívání teoretických znalostí a utváření dovedností, při kterém studenti potvrzují, upravují či vyvracejí informace získané z dostupných zdrojů. Cílem je také praktická aplikace zásad trvalé udržitelnosti v rámci konkrétních témat volených $s$ úzkou vazbou k zájmovému území. Na tématech pracují zpravidla tř́členné týmy, přičemž studenti jsou stimulováni ke spolupráci s kolegy z jiných oborových kombinací a ke sdílení know-how a výsledků mezi tématy. Studenti se zároveň naučí obhájit své výsledky při setkáních $s$ veřejností v zájmovém území i při publikační činnosti a účastech na konferencích v rámci vědecké komunity. Projekt má velký přínos i pro žáky ZŠ, kteří rozvíjejí klíčové kompetence, učí se získávat a kriticky hodnotit informace o zvoleném území, ověřovat je v terénu, navrhovat řešení, veřejně své návrhy prezentovat a obhájit je při setkání $s$ veřejností. Projekt tak stimuluje rozvoj žáků/studentů směřujících $\mathrm{k}$ roli uvědomělých a odpovědných občanů, kteří rozumí potřebám svého okolí a mají snahu se podílet na jeho budoucím rozvoji. Žákům i studentům je umožněno podílet se na výstupech, které jsou diskutovány se zástupci veřejné správy a místní samosprávy s cílem zohlednit či uplatnit je $v$ praxi. K didaktickým otázkám více Hynek s Hynkem (2005), Svozil (2008) a Trávníček, Trojan (2008).

$\checkmark$ aplikační rovině $v$ zájmovém území je hlavním cílem rozvíjení integrity a zájmu místní komunity o obec a její okolí a směřuje k aktivaci a participaci subjektů, které na Deblínsku žijí, nebo toto území nějakým způsobem ovlivňují. Aktivita žáků pomáhá vzbudit zájem místních obyvatel o okolí jejich bydliště, rozvíjí jejich citlivost $\mathrm{k}$ principům udržitelného rozvoje, př́padně je stimuluje k aktivnímu zapojení do projektu, přirozeně vtahuje rodiče a aktivní občany do projektu.

\section{Postup projektu}

Naznačená posloupnost projektu je v základních rysech obdobná pro studenty Geografického ústavu i žáky základní školy. Jednotlivé kroky jsou vzájemně provázané, často se prolínají a výsledky předchozích fází ovlivňují další postup:

1. mentální mapování - jedinečná osobní reprezentace reality, která je denně používaná $\mathrm{k}$ orientaci a pohybu v území, neustále vyhodnocovaná a zpřesňovaná (Lynch 1960); mentální mapy doplnily řízené rozhovory umožňující jejich interpretaci, 
2. vymezení území s vazbou na výsledky mentálního mapování,

3. sběr dostupných dat a řízené rozhovory s významnými aktéry,

4. profil Deblínska - výstižný obraz obce, katastru a jeho krajiny,

5. vytvoření seznamu významných problémových témat,

6. setkání žáků a studentů v prostorách ZŠ Deblín a společná práce v terénu,

7. vytváření výstupů a veřejná prezentace výsledků $v$ prostorách městyse Deblín,

8. společné exkurze a rozpracování problémů vyžádané veřejností či zástupci úřadů,

9. hledání možností pro finanční a organizační zaštítění další spolupráce.

\section{Vybrané ukázky výstupů projektu}

$\checkmark$ následujícím textu jsou představeny príklady témat a syntéza nejdůležitějších poznatků. $Z$ důvodu omezeného prostoru tento príspěvek představuje pouze několik př́kladů studovaných témat. Není proto např. zmíněn profil území, který výstižně charakterizuje studované území, nebo práce s historickými podklady, kdy žáci/studenti vytvářeli tabulku i graf vývoje počtu obyvatel a počtu domů od roku 1839; identifikovali historickou i novou náves obce, kterou zakreslili do připravených mapových podkladů. Při studování vazebnosti si např. nejen zjištovali, odkud další žáci (spolužáci) do základní školy dojiždějí, ale zjištovali také například, kam rodiče a další občané Deblína nejčastěji vyjiždějí za prací a službami. Dojezdovou vzdálenost nevyjadřovali pouze $v$ kilometrech, ale i prostřednictvím času $v$ minutách. Nahlédli i do územního plánu obce, kde se seznámili s připravovanou výstavbou, kterou společně s výstavbou probíhající opět zakreslili do připravených mapových podkladů. Identifikovali nevyužívané plochy/objekty a navrhli možnosti jejich dalšího využití, identifikovali také objekty, u kterých byl změněn účel jejich využívání, a věnovali se tomu, proč $\mathrm{k}$ tomu došlo; pátrali i po objektech, které již zcela zanikly (např. deblínský hrad). Jedno z velice kreativních témat bylo zaměřeno na vize žáků/studentů: Jak bude Deblín vypadat za 10 let?

Tř́generační proměny zaměstnanosti v rámci struktury národního hospodářství (lokálně orientované téma řešené žáky Zš Deblín)

Žáci ZŠ pochopili složitou problematiku časových změn ve struktuře zaměstnanosti $v$ sektorech národního hospodářství na př́kladě vlastní rodiny. Posunutí těžiště zaměstnanosti směrem $\mathrm{k}$ terciárnímu sektoru dali do souvislostí se změnou využívání katastru (současná extenzifikace, snížení podílu orné půdy), vývojem (ne)zaměstnanosti, zvýšení vyjižd'ky za prací a se stále menším kontaktem místních obyvatel s extravilánem obce. Žáci zároveň vtáhli své rodiče a prarodiče do děje a zamýšleli se nad svým žebrríčkem hodnot pro budoucí uplatnění na trhu práce i nad budoucností celého Deblínska a jeho obyvatel. 
Obr. 2: Pracovní formulář (vlevo) a výsledná syntéza průzkumu prováděného žáky Zš Deblín

\begin{tabular}{|c|c|c|c|}
\hline $\begin{array}{l}\text { Ve Kterém sektors } \\
\text { pracovali? }\end{array}$ & I. & II. & III. \\
\hline $\begin{array}{r}\text { L. generace: pradédečck } \\
\text { prababicka }\end{array}$ & 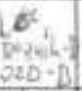 & & \\
\hline $\begin{array}{l}\text { 2. generace: dedočck } \\
\text { bahicka }\end{array}$ & ogas & & \\
\hline $\begin{array}{l}\text { 3. generace: tatinck } \\
\text { maminka }\end{array}$ & & & \\
\hline Cim cha byt jâ? & & & \\
\hline
\end{tabular}

\begin{tabular}{|c|c|c|c|c|c|}
\hline \multirow{2}{*}{ GENERACE } & \multicolumn{4}{|c|}{ SEKTORY NÁRODNIHO HOSPODARSTVI } & \multirow{2}{*}{$\begin{array}{c}\text { NEJCAASTEJSII } \\
\text { POVOLÁNI }\end{array}$} \\
\hline & PRIMER & SEKUNDER & TERCIÉR & KVARTER & \\
\hline 1. generace & 705 & $17 \%$ & $10 \%$ & $3 \%$ & 320 \\
\hline 2. generace & $45 \%$ & $35 \%$ & $20 \%$ & $0 \%$ & 320 \\
\hline 3. genersce & 65. & $45 \%$ & $39 \%$ & $10 \%$ & svaleć \\
\hline $\begin{array}{l}\text { nak oenerace } \\
\text { (baci-25) }\end{array}$ & TS & $40 \%$ & $46 \%$ & $7 \%$ & bovabe cover \\
\hline
\end{tabular}

\section{Vazby obcí na centrální Deblín (téma řešené v širším kontextu prostorových vztahů studenty vš)}

Téma hodnotí nodální vazby okolních sídel na Deblín jakožto centrum Dobrovolného svazku obcí, jehož oprávněnost je kriticky zhodnocena. Studenti rozlišili význam historického vývoje (zaměřili se na změny využívání země s využitím starých map, kroniky, vývoj administrativního členění), fyzickogeografických determinant (mapové podklady připravili studenti VŠ) i sociální struktury vztahů a kontaktů. Studovali změny využití země, zřetelnou degradaci krajiny vytvořením velkých bloků orné půdy - zhoršení vodní bilance krajiny: zrychlený odtok vody, zmenšení zásob podzemních vod, pokles rozmanitosti flóry i fauny. Žáci využívali mapové podklady připravené studenty univerzity, pečlivě zkoumali své okolí - intravilán obce, polní cesty, okraje lesů atd.

Ty mají často větší vliv, než reálné vazby prokázané při kombinování kvantitativních a kvalitativních metod výzkumu. Výsledky práce studentů poskytují místní samosprávě nosné podklady pro přehodnocení možného členství dalších obcí (s úzkou vazbou na centrální Deblín) v Dobrovolném svazku. 


\section{Obr. 3: Zhodnocení současných a historických vazeb na centrální Deblín}
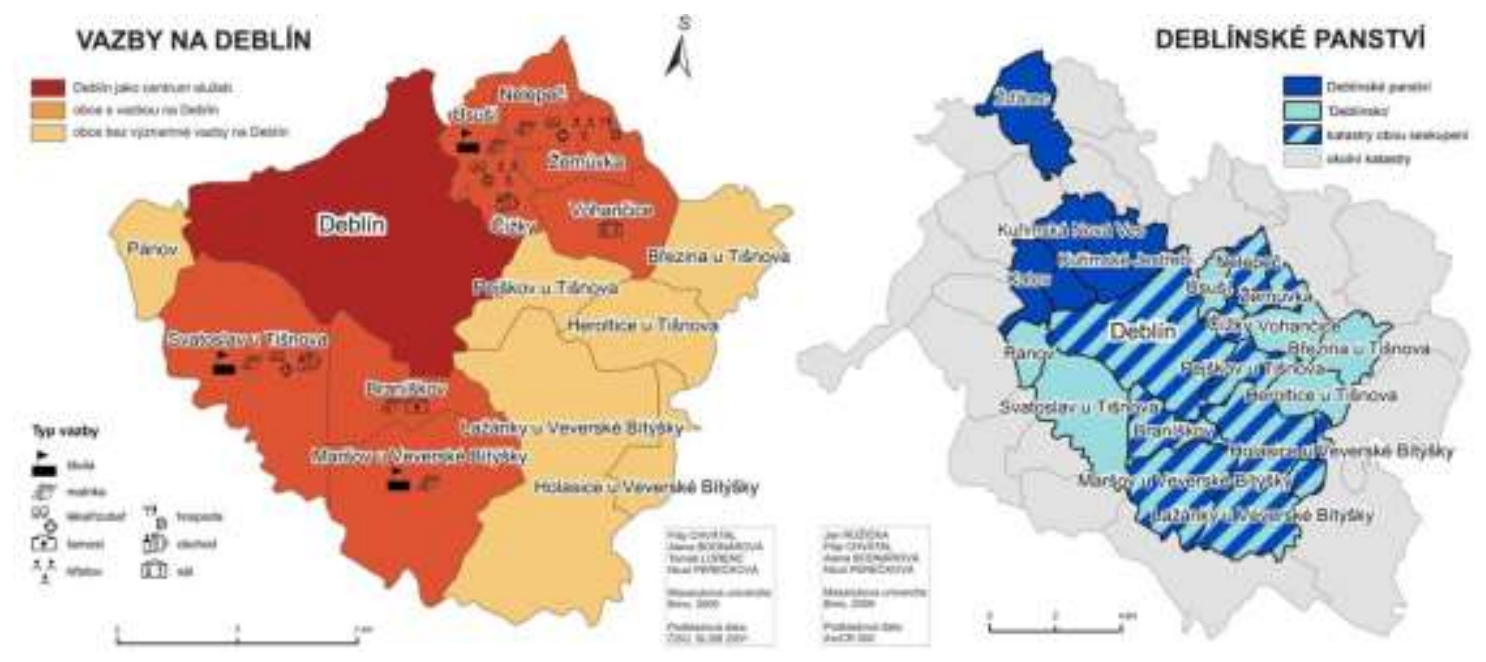

Hospodaření s vodou na Deblínsku z pohledu trvale udržitelného rozvoje (Téma řešící konkrétní otázky trvale udržitelného rozvoje v širším kontextu)

Obyvatelé Deblínska v současnosti pocitují nedostatek zdrojů vody a jejich časté znečištění. Při řešení tohoto aktuálního problému potvrdili žáci a studenti souvislost nerespektování přírodních podmínek s reálným ohrožením společnosti. Zmírnění současných projevů v krajině (eroze) i vlivu na obce (nedostatek vody jako limit rozvoje sídel) řeší návrhová část, která se stala jádrem veřejně prezentovaných a diskutovaných výsledků této skupiny. Studenti MU byli následně osloveni starostkou Vohančic (obec v severovýchodní části zájmového prostoru) s žádostí o odbornou konzultaci k hospodaření $\mathrm{s}$ vodními zdroji v rámci obce. Z rovnice vodní bilance obce Ize stanovit význam srážek a jejich jímání jako užitkové vody. Při ročním úhrnu srážek $500 \mathrm{~mm}$ Ize na střechách o ploše $100 \mathrm{~m}^{2}$ zachytit téměř $50 \mathrm{~m}^{3}$ srážkové vody.

Obr. 4: Zóny míry rizika (vpravo) a návrh opatření z pohledu trvale udržitelného hospodaření s vodou v zájmovém území; grafické řešení pro poster

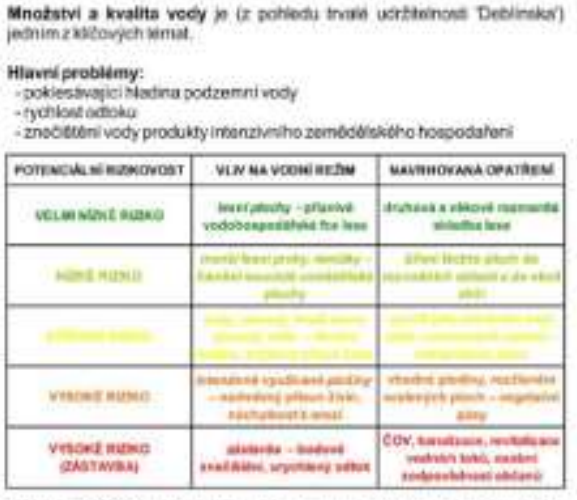

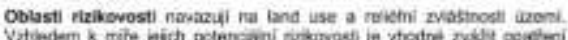

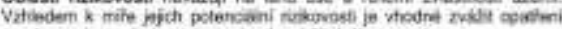

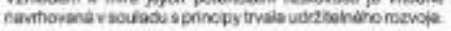

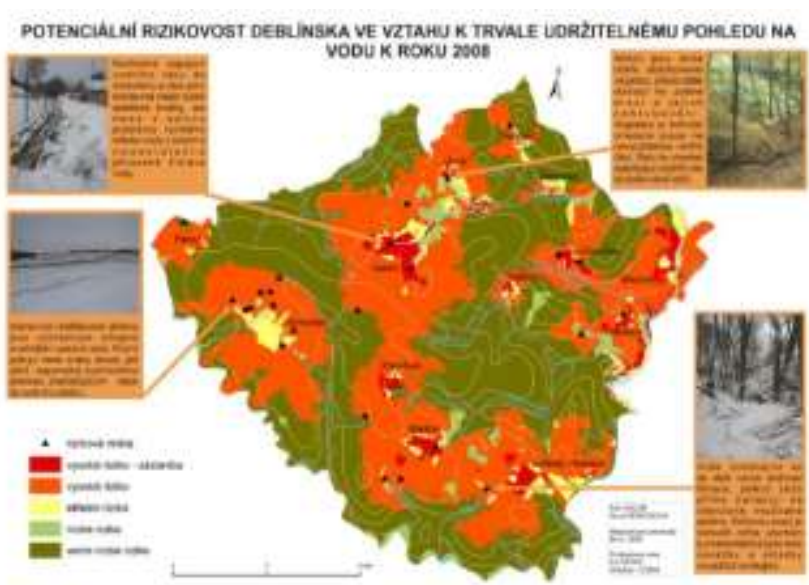


Vývoj krajiny v katastru Deblína na historických mapách (prưřezové multidisciplinární téma využívající sofistikovaných metod výzkumu)

Interpretace historických map a analýza využívání krajiny potvrdily, že se $\checkmark$ minulosti často hospodařilo ve shodě s principy udržitelného rozvoje ( $i$ když nebyl věcně definován), zatímco dnes jsou jeho principy teoreticky zpracovány a implementovány do řady dokumentů, často bez potřebného efektu. Atraktivní vizualizace výsledků pomohla nahlédnout do historie krajiny žákům ZŠ i široké veřejnosti při přednáškách v Deblíně. Občané městyse se následně $v$ diskusích zajímali o konkrétní možnosti financování krajinářských úprav.

Obr. 5: Vymezení konkrétních lokalit funkčních změn $v$ krajině (vlevo) a rekonstrukce historického využívání na podkladě map 3. vojenského mapování
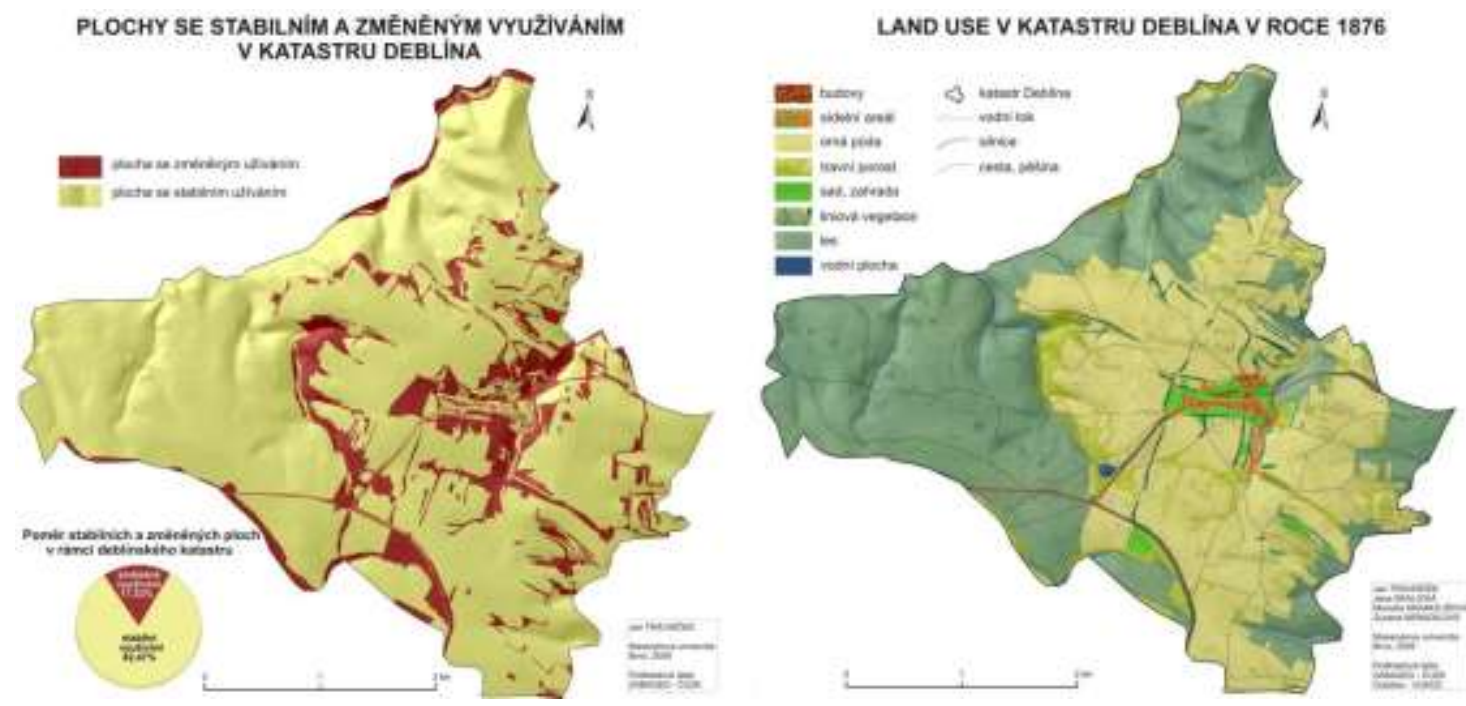
Významné krajinné prvky (VKP) v katastru Deblína (téma založené na intenzivní spolupráci žáků Zš se studenty vš)

Obr. 6: Názorná vizualizace rozmístění VKP v katastru Deblína včetně návrhů vybraných opatření; grafické řešení vhodné pro popularizaci formou přednášky i naučné tabule

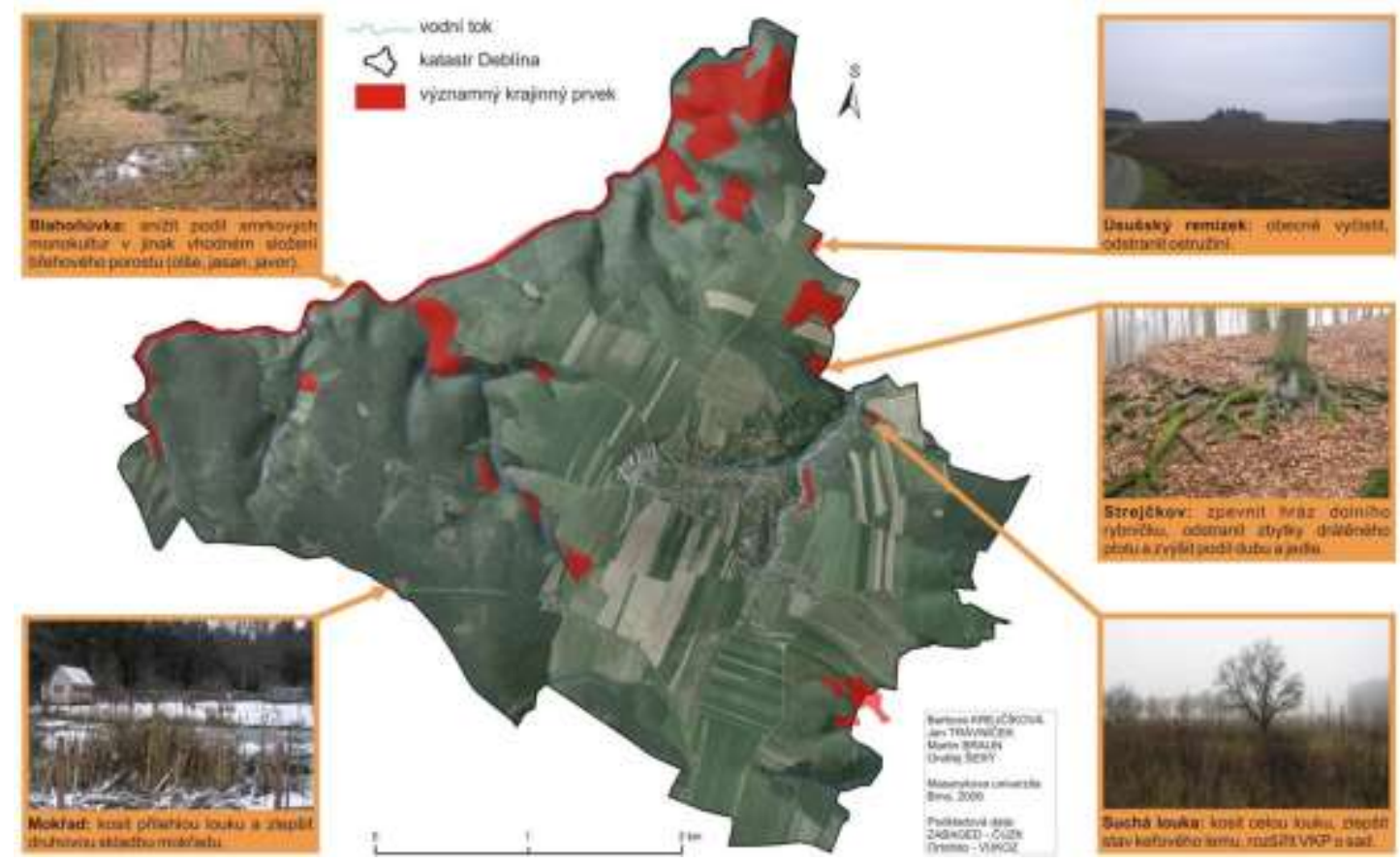

Studenti VŠ získali přístup do interního informačního systému odboru životního prostředí v Tišnově a snažili se zaktualizovat reálnou databázi významných krajinných prvků (dále VKP) u potenciálního zaměstnavatele. Skupiny žáků i studentů spolupracovaly na terénním výzkumu i při hledání možných opatření. Společná práce potvrdila význam VKP pro udržitelný rozvoj katastru a poukázala na rezervy, které má při využívání tohoto potenciálu místní samospráva. Výsledky společného mapování byly prezentovány obyvatelům městyse a okolí v rámci veřejné přednášky. Žáci ZŠ si tak za přispění svých vysokoškolských kolegů uvědomili význam trvalé udržitelnosti Deblínska, poznali místní krajinu a vyzkoušeli si veřejné vystupování (což je jedna z klíčových kompetencí definovaná požadavky trhu práce).

\section{Zhodnocení oprávněnosti volby představených témat, syntéza}

V příspěvku vybrané příklady charakteru problémů, volených přístupů a zpracování výsledků dokumentují potenciál vzdělávacího projektu. Zvolená témata umožňují provést syntézu výsledků a zasazení do širších souvislostí - uvádíme na příkladu úkolů zaměřených na významné krajinné prvky: VKP zahrnují fragmenty historických krajinných struktur vzniklých při úzkém sepětí minulých generací místních rolníků s prírodou. Fragmentované ukázky hospodaření s kořeny v období Deblínského panství jsou v posledních desítkách let pod tlakem zprůmyslněného zemědělství, kdy s krajinou hospodaří stále nižší procento ekonomicky aktivních obyvatel - navíc často bez vztahu k obhospodařované lokalitě. Zachování a volba vhodného managementu VKP může zmírňovat negativní dopady (eroze, snížení retenční schopnosti krajiny) a poskytnout nastupující generaci príklad trvale 
udržitelného modelu hospodaření s krajinou, který se v současnosti znovu prosazuje, např. ve formě (na Deblínsku př́tomného) ekologického zemědělství podporovaného na regionální, státní i mezivládní úrovni (operační programy EU).

\section{Závěr}

Kvalitativně orientovaná spolupráce na krajinném projektu Deblínsko vedla k mnoha zjištěním a návrhưm dílčích i komplexních způsobů řešení a také k porozumění a interpretaci Deblínska z pohledu místních aktérů. Spolupráce se ZŠ se jeví pro trvale udržitelný rozvoj území jako klíčová. Žáci pochopili principy trvale udržitelného rozvoje a na konkrétních tématech tyto prohloubené znalosti uplatnili při terénní práci ve svém okolí. Naučili se vnímat procesy, které utvářejí krajinu a uvědomují si, že jsou její součástí - ovlivňují ji a je jen na nich zda negativně, neutrálně či pozitivně. Své postřehy a výsledky diskutovali se spolupracujícími subjekty. To přineslo žádanou a často kritickou zpětnou vazbu. Výměny názorů respektující pravidla diskuse byly také součástí závěrečné prezentace pro veřejnost $v$ Obecním domě $v$ Deblíně, kde žáci a studenti naplno zúročili své projektové snažení. Přínos dobře charakterizuje vlastní názor žáků: „Pochopili jsme, co to zeměpis je, kolik rozmanitých znalostí získaných ve škole mưžeme v terénu využít a na jakých musíme dále pracovat". Žáci dokázali, že při vhodném vedení mohou být iniciátory řešení. Projekt byl zásadní i pro studenty MU. Při spolupráci s ostatními subjekty vyhledávali $v$ novém území trvale neudržitelné body, pro které navrhovali řešení vycházející se společného konsensu. Představený projekt ve všech směrech překročil běžně realizované pojetí dvousemestrálních cvičení zakončených zápočtem a zkouškou. O vhodnosti zvoleného přistupu svědčí pozitivní ohlasy, které přesahují studované území. Studenti úspěšně aplikovali teoretické znalosti $v$ kooperujících mezioborových týmech řešících témata vhodně volená s vazbou na zájmové území. Reálné uplatnění výsledků v praxi i v akademické sféře se ukazuje jako významný motivační aspekt. Řada studentů pokračuje ve spolupráci na projektu individuálně mimo výuku a uvítali by navázání spolupráce v dalších předmětech na Geografickém ústavu. Projekt má tedy nejen hodnotu výzkumnou, ale i vzdělávací.

Představený projekt je stále intenzivněji podporován místní samosprávou a státní správou (prostřednictvím Měú Tišnov). Zpětná vazba od obyvatel a zúčastněných institucí poskytla klíčový feedback celého projektu a přispěla k dalšímu pokračování v následujících oblastech - správa VKP ve spolupráci s MěÚ Tišnov, řešení vodního hospodářství obce Vohančice a podání žádosti o poskytnutí dotace z Operačního programu Vzdělávání pro konkurenceschopnost.

\section{Seznam literatury}

- Alcamo, J. Et Al, (2003). Ekosystémy a kvalita lidského života: Rámec pro hodnocení. Zpráva pracovní skupiny pro koncepční rámec Ekosystémového hodnocení milénia. Praha: Ministerstvo životního prostředí.

- Cloke, P., Cook, I., Crang, P., Goodwin, M., Painter, J., Philo, C, (2004). Practising Human Geography. London: Sage Publications.

- Crang, M., Thrift, N, (2000). Thinking Space (Critical Geographies). London: Routledge.

- Fay, B. (2002). Současná filosofie sociálních věd: Multikulturní přístup. Praha: Sociologické nakladatelství.

- Foucault, M. (2009). Zrození biopolitiky. Brno: Centrum pro studium demokracie a kultury.

- Holt-jensen, A. (2001). Geography - History and Concepts. A Student's Guide. London: SAGE Publications. 
- Hynek, A. (2005) Hledání trvalé udržitelnosti kraje Vysočina - pole spolupráce univerzity, soukromého a veřejného sektoru. In J. DlouhÝ \& J. DlouhÁ (Eds.), Co znamená udržitelnost pro univerzity? Sborník mezinárodní konference, Praha 5. - 6. září 2005. Příspěvek Fóra vysokoškolských učitelů k Dekádě vzdělávání pro udržitelný rozvoj OSN. Sustainability at Universities in the Czech Republic: What Are the Possibilities. The Forum of University Teachers contributes to the UN Decade of Education for Sustainable Development (pp. 90100). : UK COŽP.

- Hynek, A., Hynek, N, (2007). Bridging the gap between the theory and practice of regional sustainability: a political-conceptual analysis. Geografický časopis, 59, 49-64.

- Hynek, A., Hynek, N, (2007) Environmentální témata: kontext prostorovosti a vládnutí. In S. Kraft et al. (Eds.), Česká geografie v evropském prostoru (pp. 352-359). České Budějovice: Jihočeská univerzita.

- Hynek, A., Hynek, N, (2005) Sustainability, Development and Security in Landscape Field Practice. In K. Donert \& P. Charzyński (Eds.), Changing Horizons in Geography Education,Geography in European higher education 2 (pp. 308-313). Toruń: Herodot Network, Association of Polish Adult Educators.

- HYNEK, A., HYNEK, N., HERBER, V., SCHREFEL, Ch, (2007). Environmental Security inBorderland Areas: Exploring the Znojmo/Retz Transborder Region. Vinna: 17\&4 Organisations-beratung.

- Hynek, A., Hynek, N., Svozil, B, (2008) Geo- and Bio-Political Administration of Human Life in Borderline Landscapes: Insights from the Klentnice/Drasenhofen Transborder Region. In $\mathrm{H}$. Svatoňová (Ed.), Geography in Czechia and Slovakia: Theory and Practice at the Onset of 21st Century(pp. 308-316). Brno: MU.

- Latour, B. (2005). Reassembling the social- an introduction to actor-network-theory. Oxford: Clarendon.

- $\quad$ Lynch, K. (1960). The Image of the City. Cambridge, Massachusetts: MIT Press.

- Murdoch, J. (2006). Post-structuralist geography - a guide to relational space. London: Sage publ.

- Svozil, B. (2008). Trvalá udržitelnost Deblínska. Učitelské noviny, 45, 17-18.

- Svozil, B., TrÁvnÍČek J, (2007) Hledání strategie udržitelnosti a bezpečnosti obce Klentnice. In Študentská vedecká konferencia. Zborník recenzovaných príspevkov. 2 zväzok (pp. 259261). Bratislava: Kartprint.

- Svozil, B., Trávníček, J., Trojan., , \& Št'astný, O. Přeshraniční krajinné ekosystémy Jihomoravského kraje. In Mladí vedci 2008 - Vedecké práce doktorandov a mladých vedeckých pracovníkov (pp. 498-507). Nitra: FPV UKF v Nitre.

- TASHAKKORI, A., TEDDLIE, Ch, (2003). Handbook of mixed methods in social \& behavioral research. Thousand Oaks: SAGE Publications.

- TASHAKKori, A., TEDDliE, Ch, (1998). Mixed methodology: Combining qualitative and quantitative approaches. Thousand Oaks: SAGE Publications.

- Trávníček, J., \& Trojan, J. (2008). Project training in landscape research at Institute of Geography, Brno. GeoScape, 3(1), 73-79.

- Whatmore, S. (2002). Hybrid Geographies. Natures, Cultures and Spaces. London: Space. 
Časopis Envigogika vydává Centrum pro otázky životního prostředí UK. Vývoj časopisu je podpořen projektem OP VK Mezioborová sít udržitelného rozvoje.

Více najdete na internetových stránkách projektu mosur.czp.cuni.cz
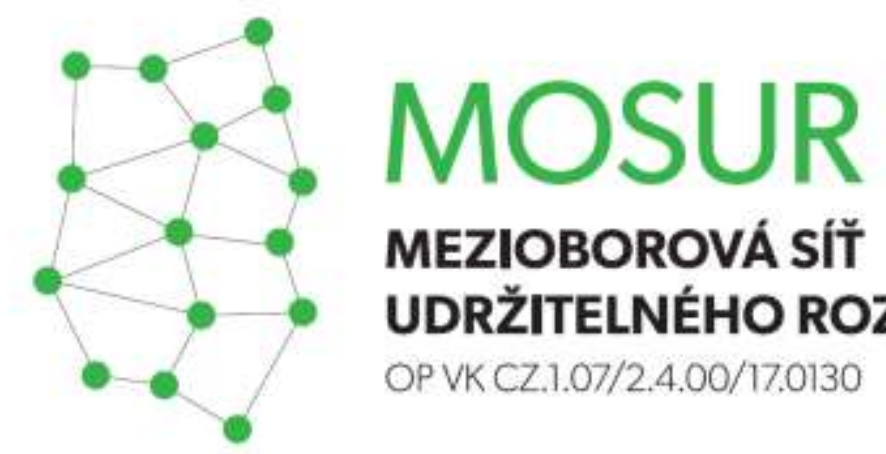

\section{MEZIOBOROVÁ SÍT} UDRŽITELNÉHO ROZVOJE

OP VK CZ.1.07/2.4.00/17.0130
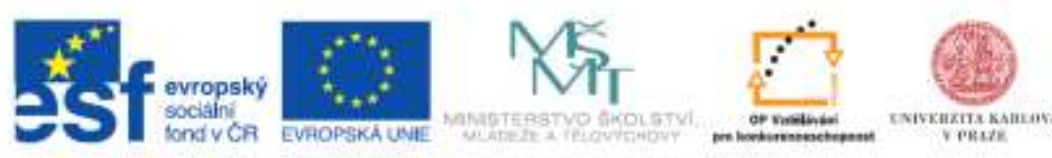

INVESTICE DO ROZVOJE VZDELAVANI 